博文静, 肖炎, 王莉雁,王效科,欧阳志云.生态资产核算及变化特征评估一一内蒙古兴安盟为例.生态学报, 2019,39(15)：-

Bo W J, Xiao Y, Wang L Y, Wang X K, Ouyang Z Y.Assessment of the status of ecological assets and variation of its characteristics: A case study of Hinggan League, Inner Mongolia.Acta Ecologica Sinica, 2019,39(15): - .

\title{
生态资产核算及变化特征评估
}

以内蒙古兴安盟为例

\author{
博文静 ${ }^{1,2}$, 肖 炏 ${ }^{1}$, 王莉雁 ${ }^{1,2}$, 王效科 ${ }^{1}$, 欧阳志云 ${ }^{1, *}$ \\ 1 中国科学院生态环境研究中心,城市与区域生态国家重点实验室, 北京 100085 \\ 2 中国科学院大学, 北京 100049
}

\begin{abstract}
摘要:十八大提出要探索编制自然资源资产负债表,对领导干部实行离任审计。生态资产是自然资源资产的重要组成部分,生 态资产核算对完善自然资源负债表编制具有一定的意义。以兴安盟为例,通过对森林、灌丛、草地和湿地生态资产数量、质量和 变化情况的评估,核算了兴安盟生态资产综合指数,即反映生态资产数量和质量的综合指标; 编制了生态资产实物量变化表和 生态资产实物量损益表。结果表明,2000-2010 年,兴安盟森林面积增加 $1.1 \%$,草地、湿地面积分别下降 $1.7 \%$ 、3.8\%,但森林和 草地的质量提高显著, 所以生态资产综合指数提高了 $2.16 \%$ 。生态资产核算作为评价领导干部在任期间是否落实生态环境质 量底线、生态保护红线要求的有效工具,为推动兴安盟生态文明建设提供一定的参考。
\end{abstract}

关键词:生态资产核算;变化特征;生态资产综合指数;兴安盟

\section{Assessment of the status of ecological assets and variation of its characteristics : A case study of Hinggan League, Inner Mongolia}

\author{
BO Wenjing ${ }^{1,2}$, XIAO Yi ${ }^{1}$, WANG Liyan ${ }^{1,2}$, WANG Xiaoke ${ }^{1}$, OUYANG Zhiyun ${ }^{1, *}$ \\ 1 State Key Laboratory of Urban and Regional Ecology, Research Center for Eco-Environmental Sciences, Chinese Academy of Sciences, Beijing \\ 100085, China \\ 2 University of Chinese Academy of Sciences, Beijing 100049, China
}

\begin{abstract}
The 18th National Congress proposed that we should explore the preparation of natural resource balance sheets and inform governmental officials using off-office auditing of natural resources. Ecological assets are an important part of natural resource assets; therefore, ecological asset accounting will be of vital significance to the preparation of natural resource balance sheets. Based on the assessment of the quantity and quality of ecological assets, which included forests, brushwood, grasslands, and wetlands, we obtained the comprehensive index of ecological assets. Furthermore, we prepared the ecological assets physical quantity balance sheet and physical quantity of increase and decrease statement. The results showed that the forested area of Hinggan League increased 1.1\%, and the area of grassland and wetland decreased $1.7 \%$ and $3.8 \%$, respectively, during the 2000s. However, the quality of forest and grassland improved significantly; therefore, the comprehensive index of ecological assets increased 2.16\%. Use of ecological asset accounting could be an effective tool to inform the governmental officials whether they meet the requirements of ecological protection, which will promote the construction of the ecological civilization of the Hinggan League.
\end{abstract}

基金项目: 国家重点研发计划(2016YFC0503402)

收稿日期: 2017- 12- 19; 网络出版日期: 2019-00-00

*通讯作者 Corresponding author.E-mail: zyouyang@ rcees.ac.cn 
Key Words: ecological assets accounting; variation characteristics; the comprehensive index of ecological assets; Hinggan League

生态系统是支撑经济社会发展和人类福祉的重要基础 ${ }^{[1-2]}$ 。生态系统产品与服务功能在维持地球生命 支持系统中发挥着巨大的作用 ${ }^{[3]}$ 。但在经济发展过程中, 以短期经济利益为主导, 对自然资源进行过度开发 以及土地利用变化、环境污染等均可能导致生态系统面积减少、质量退化。20 世纪 60 年代以来, 全球开展了 一系列的环境保护运动, 但根据《千年生态系统评估》结果, 仍有 $60 \%$ 的生态系统存在不同程度的退化 ${ }^{[4]}$ 。生 态系统和生物多样性经济学项目组 (TEEB) 预测, 未来 50 年生态系统退化造成的损失将占 GDP 的 $7 \%$ 。年] 为 了保护自然资源和生态系统, 1993 年联合国统计司 (UNSD)、世界银行等组织编制了《1993 年国民核算手册: 综合环境和经济核算》(SEEA-1993 $)^{[6]}$, 尝试将自然资源与环境纳人国民经济体系。同时, 英国、苏格兰等也 在全国尺度对生态系统和自然资源进行评估和核算 ${ }^{[7-8]}$ 。

我国目前也在积极探索将自然资源纳人核算体系。十八届三中全会指出要“加快生态文明制度建设,健 全国家自然资产管理体制,探索编制自然资源资产负债表” ${ }^{[9-10]}$ ，《生态文明体制改革总体方案》也提出要“制 定自然资源资产负债表编制指南,构建土地资源、森林资源等的资产和负债核算方法。建立实物量核算账户， 定期评估自然资源资产变化状况”。

自然资源资产包括矿产资源、土地资源、气候资源与生态资源等的资产,生态资产是重要的自然资源资 产 ${ }^{[11]}$ 。关于生态资产的概念, 部分学者认为, 生态资产是资源直接价值和生态系统服务价值的总和 ${ }^{[12-14]}$; 另 一部分学者认为, 生态资产指具有物质及环境生产能力并能为人类提供服务和福利的生物或生物衍化实体, 主要包括化石能源和生态系统 ${ }^{[15]}$ 。我们认为, 生态资产不包括化石能源, 是能够为人类提供生态产品和服务 的自然资产,包括森林、灌丛、草地、湿地、荒漠等自然生态系统, 以及农田、人工林、人工草地、城镇绿地等以自 然生态过程为基础的人工生态系统 ${ }^{[16]}$ 。

国内关于生态资产核算的研究多数侧重于价值量的核算, 如张颖 等 $^{[17]}$ 编制了森林资源资产的实物量核 算账户和价值量核算账户; 蒋洪强等 ${ }^{[18]}$ 对京津冀区域生态资产负债核算进行了研究,核算了耕地、园地、林 地、草地和水域的生态产品供给的价值量以及核算期初和期末变化量; 王娟娟等 ${ }^{[19]}$ 核算了中山市五桂山林地 资产的期初和期末价值,以及污染治理等负债情况。

我们认为, 生态资产的实物量是价值量的基础,但目前价值量的评价指标尚不统一,评价方法有待于进一 步完善。所以本研究仅对生态资产实物量进行核算。实物量核算包括生态资产的面积和质量两个方面。根 据生态资产面积和质量在核算期初和期末的变化, 编制生态资产实物量变化表; 通过详细分析生态资产变化 的原因,编制生态资产实物量损益表。

内蒙古兴安盟作为我国重要的林区和农牧业区, 森林和草地资源丰富, 自然资源资产以生态资产为主,生 态资产核算能够摸清地区生态环境质量状况,揭示生态资产管理开发利用中存在的问题,促进领导干部履行 生态资产管理和生态环境保护责任,为推动兴安盟生态资产干部离任审计提供一定的参考。

\section{1 研究区域与数据来源}

\section{1 研究区概况}

研究区域位于内蒙古自治区东北部的兴安盟 $\left(44^{\circ} 14^{\prime}-47^{\circ} 30^{\prime}, 119^{\circ} 28^{\prime}-123^{\circ} 38^{\prime} \mathrm{E}\right)$, 如图 1 , 地处大兴安 岭中段的浅山丘陵地区, 山地占 $60 \%$, 丘陵和平原分别占 $20 \%$, 属于大兴安岭向松嫩平原过渡带,亦处于北方 农牧交错地带,包括森林、灌丛、草地、湿地、农田等多种景观(图 2 ${ }^{[20]}$ 。兴安盟行政区域分为 6 个县级单元, 总土地面积 $59806 \mathrm{~km}^{2}$,包括乌兰浩特市、阿尔山市、科尔沈右翼前旗、科尔沁右翼中旗、扎责特旗和突泉县。 该区属温带大陆性季风气候,光照充足, 年降水量 354.3-485.5 mm, 无霜期 110-142 $\mathrm{d}^{[21]}$ 。

\section{2 数据来源}

本研究采用的 $2000 、 2010$ 年兴安盟生态系统类型数据来源于中科院遥感所通过 TM、ETM、MODIS 等遥感 
影像解译获取;森林资源数据来源于兴安盟林业局提供的“兴安盟森林资源小班调查数据”; 河流、湖泊等水 质数据来源于兴安盟环境监测站提供的各断面的监测数据。

\section{2 研究方法}

2.1 生态资产实物量变化表编制

生态资产实物量变化表是反映地区在某一特定时 期生态资产的期初和期末存量以及在该核算期内发生 的变化情况。本研究中,生态资产实物量变化表的核算 对象为森林、灌丛、草地和湿地生态系统, 核算内容为核 算期初和期末各类生态资产的面积和质量以及变化量。

根据不同的生态系统, 设定质量评价指标 (如表 1),森林和灌丛质量采用基于像元的相对生物量密度 进行评价, 森林地上生物量能反映森林生态系统的结构 组成, 如林龄、林分类型等, 是衡量森林生产力和森林质 量的重要参数 ${ }^{[22-24]}$ 。结合原始森林调查样方, 选取兴 安盟所在植被地带内的多个原始森林样方的生物量的 均值来代表该范围内顶级群落的生物量, 以该地带的顶 级群落的生物量为分母, 生物量为分子, 得到兴安盟 的森林生态系统质量。草地质量采用植被覆盖度来评 价, 植被覆盖度作为反映地表植被生长状况的重要指标 之一, 在草地生态系统质量评价中起着重要的作 用 ${ }^{[25-26]}$ 。湿地生态资产的质量采用水质指标来评价, 湿地水环境的健康状况直接影响湿地生态系统的质量, 水质作为湿地水环境状态的基础指标, 对湿地水生物多 样性以及生态系统服务功能等都有重要的影响 ${ }^{[27-28]}$ 。

\section{2 生态资产综合指数}

生态系统面积和质量评价指标在一定程度上反映 生态系统的格局和过程, 影响生态系统的功能, 所以评 估生态资产面积和质量的变化是生态资产核算的主要 内容 ${ }^{20-30]}$,生态资产综合指数是反映森林、灌丛、草地、 湿地等生态资产面积和质量的综合指标。将生态资产

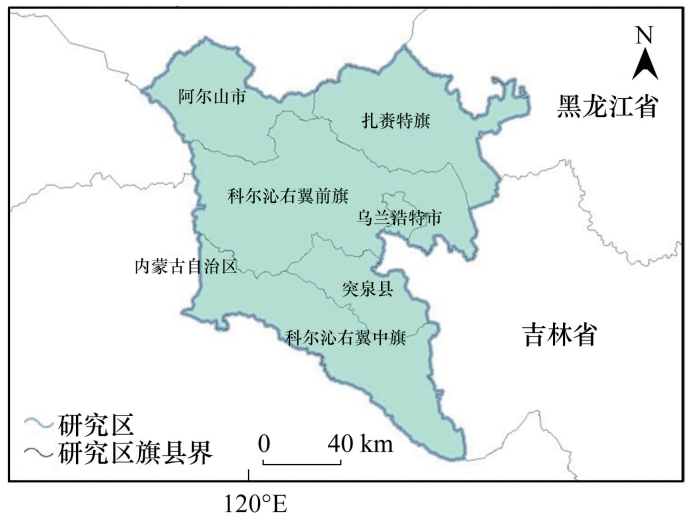

图 1 兴安盟区位图

Fig.1 Location map of Hinggan League

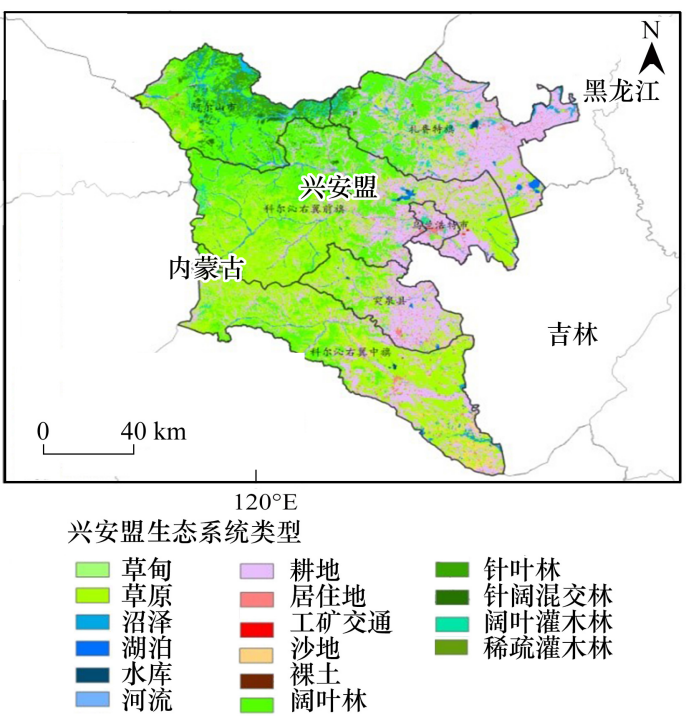

图 2 兴安盟生态系统分类图

Fig.2 Ecosystem classification map of Hinggan League 面积和质量评价指标相结合, 能够综合比较各类生态资产的时空变化。

表 1 生态资产质量分级标准

Table 1 The quality classification standard of ecological assets

\begin{tabular}{|c|c|c|c|c|c|}
\hline $\begin{array}{l}\text { 生态资产质量等级 } \\
\text { The quality classification of ecological assets }\end{array}$ & $\begin{array}{c}\text { 优 } \\
\text { Excellent }\end{array}$ & $\begin{array}{c}\text { 良 } \\
\text { Good }\end{array}$ & $\begin{array}{c}\text { 中 } \\
\text { Middle }\end{array}$ & $\begin{array}{l}\text { 差 } \\
\text { Poor }\end{array}$ & $\begin{array}{c}\text { 劣 } \\
\text { Worse }\end{array}$ \\
\hline $\begin{array}{l}\text { 相对生物量密度 } \\
\text { Relative density of biomass/\% }\end{array}$ & $\geqslant 85$ & $70-85$ & $50-70$ & $25-50$ & $<25$ \\
\hline 植被覆盖度 Vegetation coverage/\% & $\geqslant 85$ & $70-85$ & $50-70$ & $25-50$ & $<25$ \\
\hline 水质 Water quality classification & I类 & II 类 & III 类 & IV 类 & $\mathrm{V}$ 类和劣 $\mathrm{V}$ 类 \\
\hline
\end{tabular}




$$
E Q=\frac{\sum_{i=1}^{n} \sum_{j=\beta}^{j=\gamma}\left(E A_{i j} \times j\right)}{\left(\sum_{i=1}^{n} E A_{i} \times \gamma\right)} \times \frac{\sum_{i=1}^{n} E A_{i}}{9600000} \times 10^{4}
$$

式中, $E Q$ : 生态资产综合指数; $i$ : 第 $i$ 类生态资产 $; n$ : 核算的生态资产类型总数; $j$ : 第 $j$ 等级生态资产质量系 数; $\beta$ : 最低等级生态资产质量系数; $\gamma$ : 最高等级生态资产质量系数; $E A_{i j}$ : 第 $i$ 类生态资产第 $j$ 等级的面积; $E A_{i}$ : 第 $i$ 类生态资产的面积。

\section{3 结果分析}

\section{1 生态资产实物量变化表}

生态资产实物量变化表是记录不同质量的生态资产期初和期末存量以及在该核算期内发生的变化情况。 实物量变化表核算期为 2000 年到 2010 年,计算核算期内不同质量等级生态资产实物量的变化情况。

2010 年兴安盟生态资产以草地、农田和森林为主, 草地面积为 1.78 万 $\mathrm{km}^{2}$, 占总面积的 $32.4 \%$; 农田和森 林分别占总面积的 $29.6 \%$ 和 $28.2 \%$; 湿地、灌丛和荒漠生态资产面积仅占总面积的 $4.7 \%$ 、1.6\% 和 $1.3 \%$ 。生态 资产总体质量以中级和良级为主, 分别占 $38.6 \%$ 和 $30.2 \%$ (图 3)。

2000-2010 年, 兴安盟生态资产面积变化情况见表 2, 质量变化格局如图 4。森林面积增加了 $1.1 \%$,森林 质量小幅提高, 其中, 中级及以上面积增加了 $18.4 \%$, 差级和劣级面积减少了 $26.0 \%$; 灌丛面积无显著变化, 灌 丛质量有所下降, 其中差级及以上面积减少了 $28.4 \%$, 劣级面积增加了 $8.3 \%$; 草地面积减少了 $1.7 \%$, 质量呈 小幅提高,中级及以上面积增加了 $6.1 \%$, 差级和劣级面积减少了 $5.3 \%$; 湿地面积有小幅下降,降幅 $3.8 \%$,湿 地质量无显著变化,均为良级。综合来看, 2000-2010 年兴安盟生态资产总面积减少了 $0.6 \%$,生态资产质量 小幅提高,中级及以上面积提高了 $5.9 \%$,差级和劣级面积减少了 $16.2 \%$ (图 5 和图 6)。

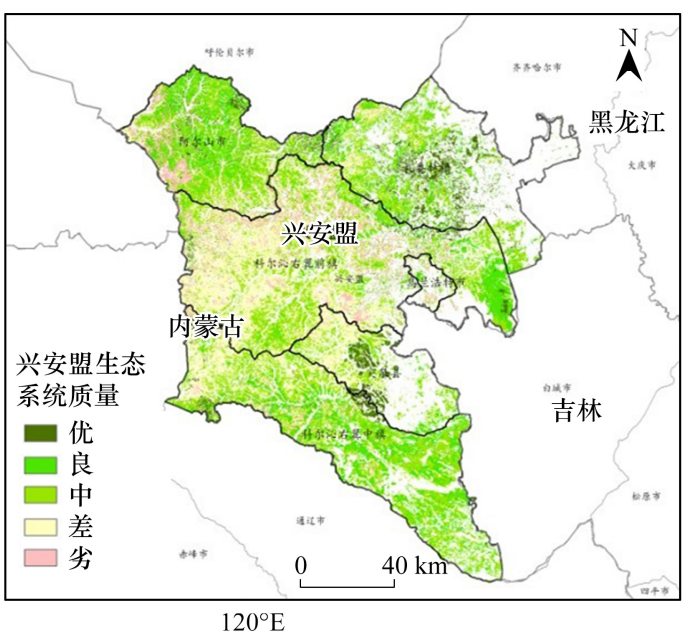

图 3 生态系统质量格局(2010 年)

Fig.3 The pattern of ecosystem quality of Hinggan League (2010)

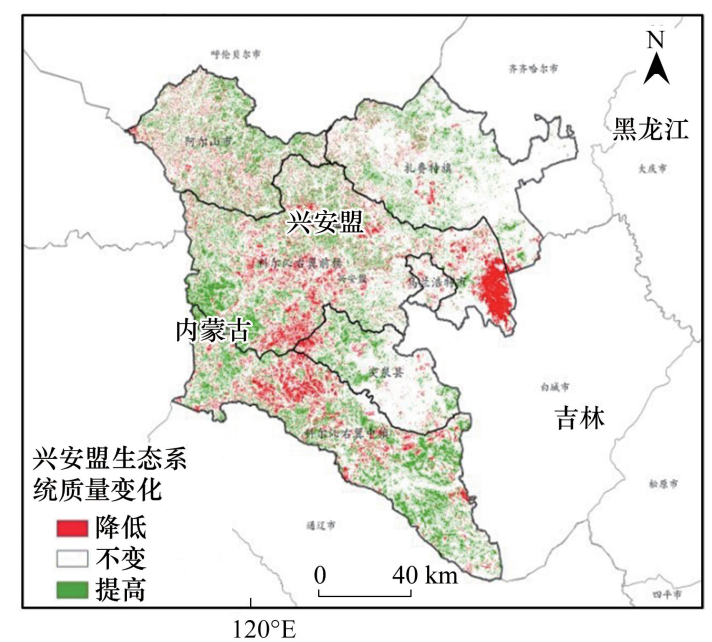

图 4 生态系统质量变化 (2000-2010 年)

Fig.4 The change of ecosystem quality of Hinggan League (20002010)

\section{2 生态资产综合指数}

2000一 2010 年, 兴安盟生态资产综合指数增加了 $2.16 \%$ 。其中, 由于森林面积和质量的小幅提高, 森林 资产指数提高了 $7.08 \%$; 随着灌丛质量的小幅下降,灌丛资产指数降低了 $8.28 \%$; 草地生态资产面积减少, 质 量小幅提高, 草地资产指数降低了 $0.39 \%$; 湿地生态资产面积小幅降低, 但质量无显著变化, 资产指数降低了 $3.83 \%$ (表 3 )。 


\section{3 生态资产转移变化}

2000一-2010 年间,兴安盟生态资产类型发生较大变化,导致变化的主要原因包括生态工程、农田开旺、生 态退化、城镇化和生态恢复五个方面 (表 4)。

从转移面积来看, 天然林保护、退耕还林和退耕还草生态工程的面积为 $179.5 \mathrm{~km}^{2}$, 占转移总面积的 $36.7 \%$; 其次是农田开唇, 转移面积为 $153.7 \mathrm{~km}^{2}$, 占转移总面积的 $31.5 \%$; 生态退化的转移面积为 $93.7 \mathrm{~km}^{2}$, 占 转移总面积的 $19.2 \%$; 城镇建设和生态恢复分别占总转移面积的 $9.5 \%$ 和 $2.9 \%$ 。

表 2 兴安盟生态资产实物量变化表 $\left(2000-2010\right.$ 年) $/\left(10^{2} \mathrm{~km}^{2}\right)$

Table 2 The changes in ecological assets physical account $(2000-2010)$

\begin{tabular}{|c|c|c|c|c|c|c|c|c|c|c|c|c|c|c|c|c|c|c|c|}
\hline \multirow{2}{*}{$\begin{array}{l}\text { 类别 } \\
\text { Category }\end{array}$} & \multirow{2}{*}{$\begin{array}{l}\text { 科目 } \\
\text { Sub- } \\
\text { Classification }\end{array}$} & \multicolumn{3}{|c|}{ 合计 Total } & \multicolumn{3}{|c|}{ 优 Excellent } & \multicolumn{3}{|c|}{ 良 Good } & \multicolumn{3}{|c|}{ 中 Middle } & \multicolumn{3}{|c|}{ 差 Poor } & \multicolumn{3}{|c|}{ 劣Worse } \\
\hline & & 2000 & 2010 & 变化量 & 2000 & 2010 & 变化量 & 2000 & 2010 & 变化量 & 2000 & 2010 & 变化量 & 2000 & 2010 & 变化量 & 2000 & 2010 & 变化量 \\
\hline \multirow[t]{4}{*}{ 森林 Forest } & 森林小计 & 153.8 & 155.6 & 1.7 & 12.4 & 14.4 & 2.1 & 28.3 & 33.7 & 5.4 & 53.4 & 63.1 & 9.7 & 51.4 & 37.2 & -14.2 & 8.4 & 7.1 & -1.3 \\
\hline & 针叶林 & 17.3 & 17.3 & 0.0 & 0.1 & 0.2 & 0.1 & 0.6 & 1.3 & 0.7 & 3.3 & 6.2 & 2.9 & 11.7 & 8.6 & -3.1 & 1.5 & 0.9 & -0.6 \\
\hline & 阔叶林 & 134.3 & 136.0 & 1.7 & 12.2 & 14.2 & 2.0 & 27.5 & 31.9 & 4.4 & 48.8 & 55.6 & 6.7 & 38.9 & 28.2 & -10.7 & 6.8 & 6.1 & -0.7 \\
\hline & 针阔混交林 & 2.2 & 2.2 & 0.0 & 0.0 & 0.0 & 0.0 & 0.2 & 0.5 & 0.3 & 1.2 & 1.3 & 0.1 & 0.8 & 0.4 & -0.4 & 0.0 & 0.0 & 0.0 \\
\hline 灌丛 Shrub & 落叶灌丛 & 8.7 & 8.7 & 0.0 & 0.0 & 0.0 & 0.0 & 0.2 & 0.1 & -0.1 & 0.4 & 0.3 & -0.1 & 1.4 & 1.1 & -0.3 & 6.7 & 7.3 & 0.6 \\
\hline 草地 Grassland & 草地 & 181.5 & 178.4 & -3.1 & 8.5 & 8.7 & 0.2 & 48.3 & 51.5 & 3.2 & 82.6 & 78.6 & -4.0 & 40.7 & 39.0 & -1.7 & 1.5 & 0.7 & -0.8 \\
\hline \multirow[t]{4}{*}{ 湿地 Wetland } & 湿地小计 & 26.4 & 25.4 & -1.0 & 0.0 & 0.0 & 0.0 & 26.4 & 25.4 & -1.0 & 0.0 & 0.0 & 0.0 & 0.0 & 0.0 & 0.0 & 0.0 & 0.0 & 0.0 \\
\hline & 沼泽 & 22.2 & 21.5 & -0.7 & 0.0 & 0.0 & 0.0 & 22.2 & 21.5 & -0.7 & 0.0 & 0.0 & 0.0 & 0.0 & 0.0 & 0.0 & 0.0 & 0.0 & 0.0 \\
\hline & 湖泊 & 2.1 & 1.8 & -0.3 & 0.0 & 0.0 & 0.0 & 2.1 & 1.8 & -0.3 & 0.0 & 0.0 & 0.0 & 0.0 & 0.0 & 0.0 & 0.0 & 0.0 & 0.0 \\
\hline & 河流 & 2.1 & 2.1 & 0.0 & 0.0 & 0.0 & 0.0 & 2.1 & 2.1 & 0.0 & 0.0 & 0.0 & 0.0 & 0.0 & 0.0 & 0.0 & 0.0 & 0.0 & 0.0 \\
\hline
\end{tabular}

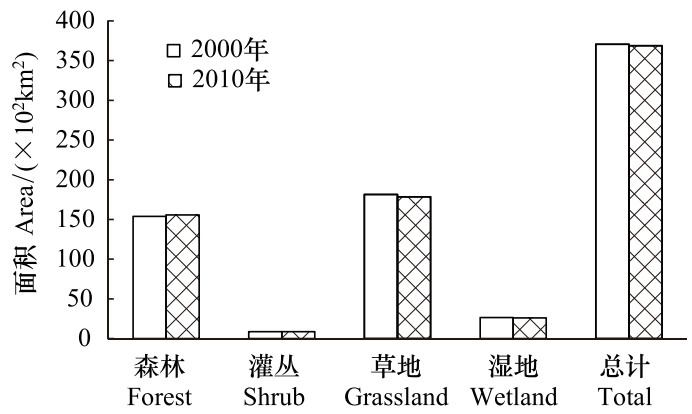

图 5 兴安盟各类生态资产面积 (2000-2010 年)

Fig.5 The area of ecological assets in Hinggan League (20002010)

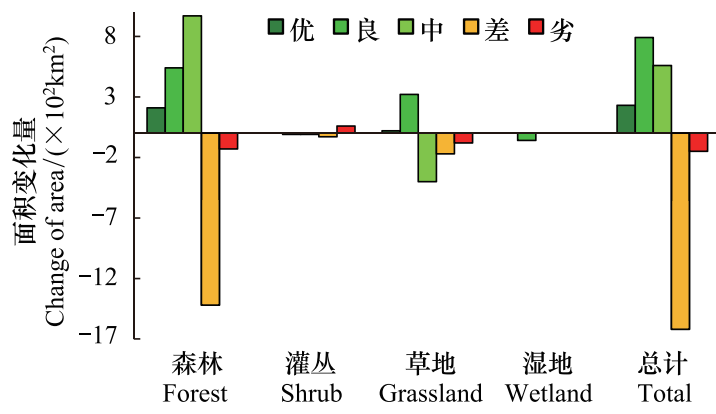

图 6 兴安盟各类生态资产不同质量等级的面积变化 (20002010 年)

Fig.6 The changes of ecological assets area in different quality grades in Hinggan League (2000-2010)

表 3 兴安盟生态资产指数变化

Table 3 The changes in ecological assets index of Hinggan League

\begin{tabular}{|c|c|c|c|c|c|}
\hline 年份 & 生态资产综合指数 & 森林资产指数 & 灌丛资产指数 & 草地资产指数 & 湿地资产指数 \\
\hline Year & Ecological asset index & Forest asset index & Shrub asset index & Grassland asset index & Wetland asset index \\
\hline 2000 & 23.53 & 9.30 & 0.24 & 11.79 & 2.20 \\
\hline 2010 & 24.04 & 9.96 & 0.22 & 11.75 & 2.11 \\
\hline 变化率 Rate of change/\% & 2.16 & 7.08 & -8.28 & -0.39 & -3.83 \\
\hline
\end{tabular}


表 4 各类型生态资产转移变化 (2000-2010)

Table 4 Land use transformation of ecological assets $(2000-2010)$

\begin{tabular}{|c|c|c|c|c|c|}
\hline \multicolumn{2}{|c|}{$\begin{array}{c}\text { 变化原因 } \\
\text { The reasons of Change }\end{array}$} & \multirow{2}{*}{2000} & \multirow{2}{*}{2010} & \multirow{2}{*}{$\begin{array}{c}\begin{array}{c}\text { 转移面积 } \\
\text { Transform area/ } \mathrm{km}^{2}\end{array} \\
145.2\end{array}$} & \multirow{2}{*}{$\begin{array}{c}\begin{array}{c}\text { 所占比例 } \\
\text { Proportion/\% }\end{array} \\
29.7\end{array}$} \\
\hline 生态工程 & 天然林保护工程 & & & & \\
\hline Ecological & 退耕还林 & 农田 & 森林 & 29.0 & 5.9 \\
\hline \multirow[t]{2}{*}{ engineering } & 退耕还草 & 农田 & 草地 & 5.3 & 1.1 \\
\hline & 生态工程小计 & & & 179.5 & 36.7 \\
\hline \multirow[t]{5}{*}{ 农田开垦 Farming } & 农田开垦 & 草地 & 农田 & 100.2 & 20.5 \\
\hline & & 湿地 & 农田 & 48.8 & 10.0 \\
\hline & & 荒漠 & 农田 & 4.3 & 0.9 \\
\hline & & 森林 & 农田 & 0.4 & 0.1 \\
\hline & 农田开垦小计 & & & 153.7 & 31.5 \\
\hline 生态退化 & 草地退化 & 草地 & 荒漠 & 69.5 & 14.2 \\
\hline Ecosystem & 湿地退化 & 湿地 & 荒漠 & 18.1 & 3.7 \\
\hline \multirow[t]{2}{*}{ degradation } & & 湿地 & 草地 & 6.1 & 1.3 \\
\hline & 生态退化小计 & & & 93.7 & 19.2 \\
\hline \multirow[t]{5}{*}{ 城镇化 Urbanization } & 城镇建设 & 农田 & 城镇 & 38.1 & 7.8 \\
\hline & & 草地 & 城镇 & 6.5 & 1.3 \\
\hline & & 森林 & 城镇 & 1.9 & 0.4 \\
\hline & & 湿地 & 城镇 & 0.1 & 0.03 \\
\hline & 城镇建设小计 & & & 46.6 & 9.5 \\
\hline 生态恢复 & 湿地恢复 & 荒漠 & 湿地 & 7.5 & 1.5 \\
\hline \multirow[t]{4}{*}{ Ecological restoration } & & 草地 & 湿地 & 2.6 & 0.5 \\
\hline & & 农田 & 湿地 & 2.1 & 0.4 \\
\hline & 草地恢复 & 荒漠 & 草地 & 2.4 & 0.5 \\
\hline & 生态恢复小计 & & & 14.6 & 2.9 \\
\hline
\end{tabular}

\section{4 生态资产实物量损益表}

生态资产实物量损益表是在生态资产转移变化的基础上,详细分析森林、灌丛、草地、湿地等各单项生态 资产期初和期末的存量, 以及存量在该核算期内发生的各类变化。生态资产存量在一个核算期内的数量变化 原因有很多,有些变化是来自人类活动的影响,如森林砍伐或人工造林; 有些变化是由自然现象引起的,如森 林火灾造成林木资源减少等。生态资产实物量损益表核算目的是评估当前的经济活动方式是否会导致现有 生态资产发生耗减和退化, 能够为生态资产管理提供有效帮助。

2000-2010 年, 兴安盟森林面积增加了 $1.1 \%$, 主要由于天然林保护和退耕还林工程造林, 贡献率分别占 $83.3 \%$ 和 $16.7 \%$ (图 7)。草地面积减少了 $1.7 \%$, 由于天然林保护工程和农田开剭, 草地转变为森林和农田, 贡 献率占比分别为 $44.8 \%$ 和 $30.9 \%$ (图 8)。湖泊、河流和沼泽面积分别减少了 $11.1 \% 、 1.9 \%$ 和 $3.3 \%$, 主要是湿地 退化和农田开剭造成的面积减少 (表 5 )。

\section{4 讨论}

本研究根据兴安盟生态资产实际情况, 对森林、灌丛、草地、湿地等生态资产的数量、质量的变化及其变动 原因进行了分析,得到兴安盟生态资产综合指数,生态资产实物量变化表以及损益表,为开展自然资源资产核 算提供一定的参考。2000-2010 年, 兴安盟生态资产综合指数提高了 $2.16 \%$, 其中生态资产面积减少了 0 . $6 \%$, 主要体现在草地和湿地面积的降低, 根据损益表分析结果, 草地面积减少的主要原因为天然林保护工程 建设和农田开剭; 湿地面积降低的主要原因为农田开垦和水库建设。10 年间兴安盟生态资产质量显著提高, 质量增加的面积约为 $6878.2 \mathrm{~km}^{2}$, 主要分布在阿尔山市东北部的天然林保护区、扎妻特旗的西北部、科右前旗 
北部以及科右中旗中部的天然林保护区以科右前旗西部的天然草地。生态资产质量降低的面积为 5781.3 $\mathrm{km}^{2}$,主要集中在科右前旗中部和东部、扎妻特旗中部、科右中旗中部和南部的连片区域 ( 图 4)。

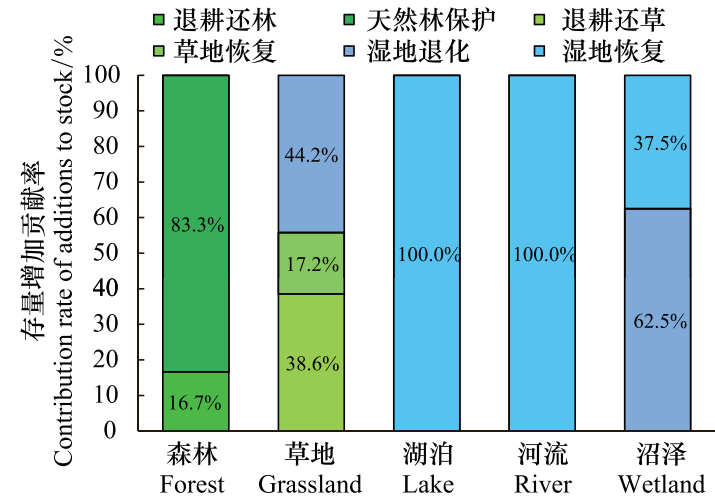

图 7 兴安盟各类生态资产存量增加贡献率

Fig.7 Contribution rate of additions to stock of ecological assets in Hinggan League

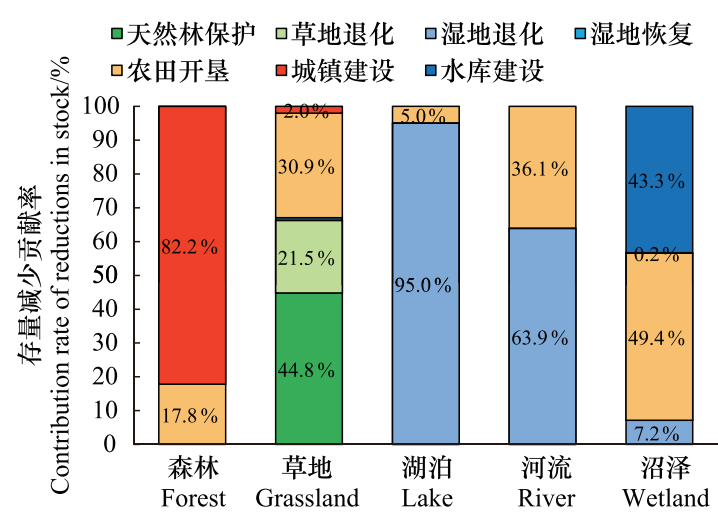

图 8 兴安盟各类生态资产存量减少贡献率

Fig.8 Contribution rate of reductions in stock of ecological assets in Hinggan League

表 5 兴安盟生态资产实物量损益表 ( 2000 - 2010 年) $/ \mathrm{km}^{2}$

Table 5 The profit and loss statement of ecological assets physical account of Hinggan League (2000-2010)

\begin{tabular}{|c|c|c|c|c|c|c|}
\hline $\begin{array}{c}\text { 核算项目 } \\
\text { Accounting items }\end{array}$ & & $\begin{array}{l}\text { 森林 } \\
\text { Forest }\end{array}$ & $\begin{array}{c}\text { 草地 } \\
\text { Grassland }\end{array}$ & $\begin{array}{l}\text { 湖泊 } \\
\text { Lake }\end{array}$ & $\begin{array}{l}\text { 河流 } \\
\text { River }\end{array}$ & $\begin{array}{l}\text { 沼泽 } \\
\text { Swamp }\end{array}$ \\
\hline \multicolumn{7}{|l|}{ 存量增加 Additions to stock } \\
\hline \multirow[t]{3}{*}{ 生态工程 Ecological engineering } & 退耕还林 & 29.01 & - & - & - & - \\
\hline & 天然林保护 & 145.22 & 5.34 & - & - & - \\
\hline & 退耕还草 & - & & - & - & - \\
\hline 生态退化 Ecosystem degradation & 湿地退化 & - & 6.12 & - & - & 13.88 \\
\hline \multirow[t]{2}{*}{ 生态恢复 Ecological restoration } & 草地恢复 & - & 2.38 & - & - & - \\
\hline & 湿地恢复 & - & - & 4.88 & 0.06 & 8.33 \\
\hline 存量总增加 Total additions to stock & & 174.15 & 13.84 & 4.88 & 0.06 & 22.21 \\
\hline \multicolumn{7}{|l|}{ 存量减少 Reductions in stock } \\
\hline 农田开层 Farming & 农田开唇 & 0.41 & 100.17 & 1.39 & 1.48 & 45.89 \\
\hline \multirow[t]{2}{*}{ 城镇化 Urbanization } & 城镇建设 & 1.89 & 6.54 & - & - & 0.14 \\
\hline & 水库建设 & - & - & - & - & 40.25 \\
\hline 生态工程 Ecological engineering & 天然林保护 & - & 145.15 & - & - & - \\
\hline \multirow[t]{2}{*}{ 生态退化 Ecosystem degradation } & 草地退化 & - & 69.52 & - & - & - \\
\hline & 湿地退化 & - & - & 26.56 & 2.62 & 6.67 \\
\hline 生态恢复 Ecological restoration & 湿地恢复 & - & 2.63 & - & - & - \\
\hline 存量总减少 Total reductions in stock & & 2.3 & 324.02 & 27.95 & 4.11 & 96.11 \\
\hline 净变化 Net change in stock & & 171.87 & -310.17 & -23.07 & -4.04 & -73.90 \\
\hline
\end{tabular}

本文在对兴安盟生态资源状况进行摸底的基础上,形成了生态资产实物量变化表和损益表的初步设计, 但还存在一定的问题: (1)在会计学中,企业资产负债表编制根据会计核算恒等式 “资产=负债+所有者权益”, 企业资产负债表是企业经济活动的静态体现 ${ }^{[31]}$ 。而生态资产实物量变化表的主要目的是揭示地区在核算期 内生态资产的数量和质量及其变动情况, 反映区域生态资产 “家底”。由于各项生态资产实物量无法累加及 相互替代,所以生态资产实物量变化表中未能体现负债相关的内容。此外,由于目前生态资产的产权尚不明 晰 ${ }^{[15]}$, 变化表中也无法体现各类生态资产的所有者权益, 所以, 本研究中生态资产变化表仅包括资产项, 未包 含负债项和所有者权益。(2)生态资产实物量损益表可以分析核算期内各类生态资产数量变化的原因,如森林 
面积的增加主要原因是人工造林,但由于缺少兴安盟天然林保护、三北防护林等其他生态工程的恢复面积,损 益表中未能体现各个生态工程的恢复效益。(3湿地质量评价中,采用不同水质级别的面积进行评价,但不同 地区水质监测完善程度不同,仅用监测断面的水质评估区域总体水质情况,具有一定的局限性,兴安盟水资源 丰富,但水质监测断面较少,未来应该逐步完善水环境监测体系,为生态资产核算提供数据支撑。

随着生态资产核算研究的不断深人,生态资源基础数据统计的不断完善以及监测水平的不断提高, 生态 资产实物量变化表的设计能更加科学合理地反映生态资产的真实状况, 为生态资产的干部离任审计的实施提 供一定的理论依据和参考。

\section{参考文献( References) :}

[ 1 ] Daily G C. Nature's Services. Societal Dependence on Natural Ecosystems[M]. Washington D C: Island Press, 1997.

[ 2 ] 欧阳志云, 王效科, 苗鸿. 中国陆地生态系统服务功能及其生态经济价值的初步研究. 生态学报, 1999, 19(5) : 607-613.

[ 3 ] Costanza R, D'Arge R, De Groot R, Farber S, Grasso M, Hannon B, Limburg K, Naeem S, O'Neill R V, Paruelo J, Raskin R G, Sutton P, Van Den Belt M. The value of the world's ecosystem services and natural capital. Nature, 1997, 387(6630): 253-260.

[ 4 ] Millennium Ecosystem Assessment. Washington D C: Island Press, 2005.

[ 5 ] TEEB. The Economics of Ecosystems and Biodiversity. 2010. http://www. teebweb. org/our-publications/teeb-study-reports/synthesisreport/\#. Ujxmnn9mOG8.

[ 6 ] United Nations. Integrated Environmental and Economic Accounting: Integrated Environmental and Economic Accounting[ M $]$. New York: United Nations, 1993.

[ 7 ] UK NEA. Synthesis of the Key Findings. UK National Ecosystem Assessment. Cambridge: UNEP-WCMC, 2011.

[ 8 ] SNH. Scotland's Natural Capital Asset (NCA) Index. 2018. https://www.nature.scot/scotlands-natural-capital-asset-index-0.

[ 9 ] 中国共产党第十八届中央委员会第三次全体会议文件汇编. 北京: 人民出版社, 2013.

［10］国务院办公厅. 编制自然资源资产负债表试点方案. (2015-11-08). https://www.chinaacc.com/zyczfg/hu1511176923.shtml.

[11］高吉喜, 李慧敏, 田美荣. 生态资产资本化概念及意义解析. 生态与农村环境学报, 2016, 32(1) : 41-46.

[12] 潘耀忠, 史培军, 朱文泉, 顾晓鹤, 范一大, 李京. 中国陆地生态系统生态资产遥感定量测量. 中国科学 D 辑: 地球科学, 2004, 34(4) : 375-384.

[13] 蒋菊生. 生态资产评估与可持续发展. 华南热带农业大学学报, 2001, 7(3) : 41-46.

[14] 马立新, 覃雪波, 孙楠, 杨国亭. 大小兴安岭生态资产变化格局. 生态学报, 2013, 33(24): 7838-7845.

[15] 高吉喜. 生态资产评估在环评中的应用前景及建议. 环境影响评价, 2014, (1) : 26-29.

[16] 欧阳志云, 郑华, 谢高地, 杨武, 刘桂环, 石英华, 杨多贵. 生态资产、生态补偿及生态文明科技贡献核算理论与技术. 生态学报, 2016, 36(22) : 7136-7139.

[17] 张颖, 潘静. 中国森林资源资产核算及负债表编制研究——基于森林资源清查数据. 中国地质大学学报, 2016, 16(6): 46-53.

[18］蒋洪强, 卢亚灵, 程䂀, 于森. 京津冀区域生态资产负债核算研究. 中国环境管理, 2016, 8(1): 45-49.

[19] 王娟娟. 中山市五桂山林地生态资产负债表研究 [D]. 长沙: 湖南师范大学, 2015.

[20] 付华, 李俊彦. 内蒙古兴安盟旅游资源单体的特征与开发. 地理研究, 2010, 29(3) : 565-573.

[21] 唐红艳, 么文, 尹肖飞. 气候变化对内蒙古兴安盟半干旱农区土壤水分的影响. 干旱地区农业研究, 2009, 27 (1): 130-134, $139-139$.

[22] 徐冰, 郭兆迪, 朴世龙, 方精云. 2000-2050 年中国森林生物量碳库: 基于生物量密度与林龄关系的预测. 中国科学: 生物科学, 2010, 40(7) : 587-594.

[23] 罗天祥. 中国主要森林类型生物生产力格局及其数学模型 $[\mathrm{D}]$. 北京: 中国科学院研究生院 ( 国家计划委员会自然资源综合考察委员 会), 1996.

[24] 肖洋, 欧阳志云, 王莉雁, 饶恩明, 江凌, 张路. 内蒙古生态系统质量空间特征及其驱动力. 生态学报, 2016, 36( 19) : 6019-6030.

[25] Purevdorj T S, Tateishi R, Ishiyama T, Honda Y. Relationships between percent vegetation cover and vegetation indices. International Journal of Remote Sensing, 1998, 19(18): 3519-3535.

[26] 杨峰, 李建龙, 钱育蓉, 杨齐, 金国平. 天山北坡典型退化草地植被覆盖度监测模型构建与评价. 自然资源学报, 2012, 27(8)： 1340-1348.

[27] 李玉凤, 刘红玉, 郝敬峰, 郑因, 曹晓. 湿地水环境健康评价方法及案例分析. 环境科学, 2012, 33(2): 346-351.

[28] 高学平, 赵世新, 张晨, 涂向阳. 河流系统健康状况评价体系及评价方法. 水利学报, 2009, 40(8): 962-968.

[29] Hein L, Obst C, Edens B, Remme R. Progress and challenges in the development of ecosystem accounting as a tool to analyse ecosystem capital. Current Opinion in Environmental Sustainability, 2015, $14: 86-92$.

[30] Tallis H, Mooney H, Andelman S, Balvanera P, Cramer W, Karp D, Polasky S, Reyers B, Ricketts T, Running S, Thonicke K, Tietjen B, Walz A. A global system for monitoring ecosystem service change. Bioscience, 2012, 62(11) : 977-986.

[31] 朱婷, 施从炀, 陈海云, 郑雪丰. 自然资源资产负债表设计探索与实证—以京津冀地区林木资源为例. 生态经济, 2017, 33(1)： 159- 166. 